\title{
Por uma análise midiática da música popular massiva Uma proposição metodológica para a compreensão do entorno comunicacional, das condições de produção e reconhecimento dos gêneros musicais
}

\author{
Jeder Janotti Junior 1 \\ UFBA \\ jeder@ufba.br
}

\begin{abstract}
Resumo: Este artigo parte do pressuposto de que o papel ocupado pela música em nosso cotidiano não se reflete diretamente nos projetos $e$ proposições analíticas oriundas do campo da comunicação. Nesse sentido, o artigo apresenta uma proposta de análise midiática da música popular massiva que leve em consideração os aspectos técnicos, econômicos e plásticos inscritos no formato canção, reiterando a importância dos estudos culturais para a compreensão dos fenômenos midiáticos. Para tanto, se faz necessário compreender a Indústria do Entretenimento, em especial da Indústria Fonográfica, seus agentes e consumidores como um dispositivo midiático que deixa marcas nos produtos da música popular massiva. Acredita-se, então, que esta contribuição teórico-metodológico é relevante para a compreensão do papel que as canções ocupam na cultura $e$ comunicação contemporâneas.
\end{abstract}

Palavras-Chave: Música Popular Massiva. Gêneros Musicais. Canção Popular Massiva, Estudos Culturais.

\footnotetext{
${ }^{1}$ Professor do Programa de Pós-Graduação em Comunicação e Cultura Contemporâneas (UFBA), coordenador o grupo de pesquisa Mídia \& Música Popular Massiva (financiados com recursos da Fundação de Apóio à Pesquisa da Bahia - Fapesb e do CNPq). Bolsista do Programa Tutorial de Ensino (PETCOM) da Faculdade de Comunicação da UFBA. Autor dos livros "Aumenta Que Isso Aí é Rock and Roll: mídia, gênero musical e identidade" (E-papers, 2003) e "Heavy Metal com Dendê: rock pesado e mídia em tempos de globalização" (Epapers, 2004).
} 


\section{Introdução}

Apesar do espaço ocupado pela música popular massiva em termos econômicos e sociais na cultura contemporânea, poucos são os estudos centrados nas especificidades da produção de sentido desses produtos culturais em seus aspectos midiáticos, que levem em consideração a formatação desse importante fenômeno comunicacional a partir da análise das estratégias midiáticas inscritas nas condições de produção e reconhecimento presentes nas canções. Assim, este artigo parte do pressuposto de que a análise dos aspectos plásticos da canção - seja através de suas configurações de gênero e/ou das performances implicadas nas canções - deve levar em consideração tanto as condições de produção (as marcas dos agentes da Indústria Fonográfica, como produtores, intérpretes e músicos), quanto as condições de reconhecimento da música (o ouvinte pressuposto nas diversas expressões do formato canção).

As condições produtivas dos discursos sociais têm a ver, ou com as determinações que dão conta das restrições de geração de um discurso e de um tipo de discurso, ou com as determinações que definem as restrições de sua recepção. Chamamos as primeiras condições de produção $\mathrm{e}$, as segundas, condições de reconhecimento. Os discursos são gerados sob determinadas condições, que produzem seus efeitos sob condições também determinadas. É entre esses dois conjuntos de condições que circulam os discursos sociais (VERÓN, 1996: 127).

A canção popular massiva torna-se então, ponto de partida para a abordagem dos aspectos sociais e culturais do consumo da música. Nessa direção, acredita-se que a dimensão plástica e material deve ser devidamente analisada para uma melhor compreensão dos aspectos midiáticos da música popular massiva. É necessário, então, identificar o modo como as estratégias discursivas que demarcam os gêneros musicais ou as marcas estilísticas de determinados músicos são forjados não só nos aspectos técnicos da execução musical, bem como nos aspectos midiáticos configurados nas técnicas de gravação, nos arranjos, nas performances e no endereçamento a um público específico.

Neste percurso, acredita-se que a abordagem da configuração da canção, dos gêneros e das performances inscritas nos aspectos plásticos da música popular massiva possibilita uma inter-relação teórico-metodológica entre pressupostos semióticos e os Estudos Culturais em suas aplicações às manifestações musicais. 
Desde já se torna necessário esclarecer que a idéia de música popular massiva está ligada às expressões musicais surgidas no século XX e que se valeram do aparato midiático contemporâneo, ou seja, técnicas de produção, armazenamento e circulação tanto em suas condições de produção bem como em suas condições de reconhecimento. $\mathrm{Na}$ verdade, em termos midiáticos, pode-se relacionar a configuração da música popular massiva ao desenvolvimento dos aparelhos de reprodução e gravação musical, o que envolve as lógicas mercadológicas da Indústria Fonográfica, os suportes de circulação das canções e os diferentes modos de execução e audição relacionados a essa estrutura.

Pode-se inclusive pensar que, tal como acontece com boa parte dos produtos que circulam através dos dispositivos da Indústria do Entretenimento, a música popular massiva está diretamente ligada ao ambiente forjado na Indústria Fonográfica. Tal ambiente compreende linguagens específicas da música massiva, os meios técnicos que possibilitam a gravação, a reprodução e a circulação da música, bem como os produtores, músicos, críticos e consumidores que circulam nas mídias musicais. Ao analista desses produtos, cabe detectar as marcas desses produtos inscritas na produção de sentido da canção popular massiva.

Sabe-se, por exemplo, que o aumento do consumo da música por uma parcela da população que não possuía conhecimento da notação musical está diretamente ligado ao aparecimento dos primeiros aparelhos de reprodução sonora: o gramofone, o fonógrafo, o rádio e o toca-discos. A própria idéia de álbum², ou seja, um produto musical com mais de quarenta minutos que configura a idéia de uma ligação entre suas diversas faixas, está diretamente relacionada ao surgimento do Long-Play, disco de vinil, de 12 polegadas, com 33 1/3 rotações por minuto que permitia aumentar a quantidade de dados armazenados, alterando assim parte das relações de consumo com a música popular massiva. O álbum, por exemplo, alterou não só pressupostos do consumo da música, como também suas estratégias de produção, uma vez que tornou necessário que produtores, compositores e intérpretes levassem em consideração a ligação entre as oito ou dez faixas, a ordem, a seqüência e a coerência das músicas - agora, lançadas ao mesmo tempo no mercado

${ }^{2} \mathrm{~A}$ idéia de álbum remete ao conjunto das canções, da parte gráfica, das letras, da ficha técnica e dos agradecimentos lançados por um determinado intérprete com um título, uma espécie de obra fonográfica. 
fonográfico, valorizando ainda mais a parte gráfica e suas relações com a expressão musical. Segundo Marchi, “(...) o LP passa a ser consumido como livros, ou seja, um suporte fechado passível de coleção em discotecas privadas - com o status de objeto cultural, afinal, julga-se a cultura musical de uma pessoa pela discoteca que possui” (2005, p.13). Hoje, pode-se perceber que tocadores de MP3 como o Ipod $^{3}$ e o armazenamento da música nos computadores pessoais já permitem pensar outros parâmetros para se pensar uma biblioteca musical, tornando em alguns casos, obsoleta a própria idéia de uma "discoteca" em sentido tradicional. Novamente, tal como na época dos discos compactos, que limitavam-se a uma música no lado A e outra no lado $\mathrm{B}$, a canção ganha uma certa independência em relação à produção global dos intérpretes da música popular massiva. Essa perspectiva torna essencial uma definição precisa dos aspectos midiáticos que envolvem a canção e seus desdobramentos através dos gêneros musicais.

\section{2- A Canção Popular Massiva}

A noção de canção popular massiva está ligada aos encontros entre a cultura popular e as artefatos midiáticos. Inicialmente, canção se refere à capacidade humana de transformar uma série de conteúdos culturais em peças que configuram letra e melodia. Segundo o pesquisador da canção brasileira Luiz Tatit (2004), o surgimento do primeiro gênero da canção popular brasileira, o samba, está diretamente relacionado ao aparecimento do gramofone, já que foram as primeiras gravações que colocaram a necessidade de repetição da letra, de uma estruturação precisa da peça musical e o reconhecimento da importância de autores e/ou intérpretes destas peças musicais:

Iniciava-se, assim, a era dos cancionistas, os bambas da canção, que se mantinham afinados com o progresso tecnológico, a moda, o mercado e o gosto imediato dos ouvintes. Nascia também uma noção estética que não podia ser dissociada do entretenimento (TATIT, 2004: p 40).

\footnotetext{
3 Drive portátil desenvolvido pela Apple e que se tornou referência do consumo de música no arquivo MP3, que é um processo de compreensão de arquivo, MPEG-1 Layer, qye permite tanto a troca e cópia de música sem a necessidade de um $\mathrm{CD}$, como sua circulação na internet através dos computadores pessoais.
} 
A regularidade rítmica e melódica favoreceu o aparecimento de peças musicais que privilegiavam o refrão e os temas recorrentes. O refrão, elemento básico da canção popular massiva, pode ser definido como um modelo melódico ou rítmico de fácil assimilação que tem como objetivos principais sua memorização por parte do ouvinte e a participação ("cantar junto") do receptor no ato de audição, sendo repetido várias vezes ao longo da canção. Nesse ponto, é possível, por exemplo, perceber uma articulação entre as estratégias técnicas, mercadológicas e plásticas do formato canção, uma vez que a repetição ligada à memorização está conectada à circulação da música na cultura contemporânea, que vai desde as teclas repeat dos tocadores de CDs e MP3s, até a espiral repetitiva que caracteriza as programações das rádios e das TVs especializadas em videoclipes. A configuração da canção em seus aspectos midiáticos está atrelada à própria capacidade de armazenamento dos primeiros discos de vinil de 45 rotações por minuto, que só reproduziam duas canções, uma de cada lado do disco, de no máximo 3 minutos, padrão que acabou servindo de referência para as rádios e os ouvintes mesmo após a ampliação da capacidade de armazenamento dos artefatos midiáticos. Tanto é que, apesar de sua discrepância à capacidade de armazenamento do suporte $\mathrm{CD}$, os singles, lançamentos de discos com duas ou quatro canções, continuam sendo lançados como peças promocionais e estão diretamente vinculados ao formato canção popular massiva.

De acordo com Luiz Tatit $(1997,2004)$ pode-se, a princípio, estruturar as diferentes formatações da canção popular em três configurações diferenciadas: 1) a tematização, caracterizada por uma regularidade rítmica centrada nas estruturas dos refrões e de temas recorrentes, como, por exemplo, as canções da Jovem Guarda e da música axé; 2) a passionalização, caracterizada por uma ampliação melódica centrada na extensão das notas musicais, exemplificada pelo samba-canção, sertanejo e "baladas" em geral e 3) figurativização, em que há uma valorização na entoação lingüística da canção, valorizando os aspectos da fala presentes nessas peças musicais, tal como acontece no rap e no samba de breque. Naturalmente, a configuração das canções não se esgota em um desses modelos. Na verdade, boa parte da produção musical massiva que possui uma poética diferenciada, como as composições de Tom Jobim ou dos Beatles, se caracteriza pela variação dessas expressões determinadas diç̧ões. Mas esse também não é um aspecto que se esgota 
na "plasticidade" das canções, uma vez que as estratégias de configuração dos intérpretes musicais passam também pela configuração de um corpo midiático, aliado às performances, histórias e depoimentos que são elementos importantes na produção de sentido da música popular massiva.

Aqui, nos apoiamos nos conceitos de Tatit para propormos a idéia de que os gêneros musicais já são indicações de determinadas dicções e estratégias midiáticas de direcionamento mercadológico da música, uma vez que, independentemente de conhecer o intérprete, o consumidor de música reconhece as melodias, temáticas e expressões de um blues, de um funk, de um samba de roda, de um chorinho ou de uma canção heavy metal.

Pode-se então, observar que, hoje, a dicção da canção popular massiva está diretamente associada a uma cadeia midiática em que os aspectos comerciais são melhor evidenciados, cujo ponto de partida é o esforço para atingir o maior número possível de ouvintes. A canção popular massiva pressupõe uma interação tensiva entre a criação e sua configuração como produto midiático. Assim, a música massiva, em seus diversos formatos, também valoriza não só a execução, bem como as técnicas de gravação/reprodução e circulação, levando em conta os timbres eletrônicos ou acústicos, a ambivalência de sons graves ou agudos, a reverberação, a sensação de extensão sonora e as estratégias discursivas que envolvem os aspectos técnicos e econômicos do ambiente comunicacional que envolve a música popular massiva. Vale lembrar que algumas expressões musicais, como a música eletrônica, não se utilizam do formato canção, mas não deixam de relacionar-se, seja através da referência ou de sua negação, a este modelo dominante da expressão da música popular massiva. Isso sem falar na inter-relação entre as estratégias midiáticas e econômica oriundas da Indústria Fonográfica que também fazem parte da expressão dessa expressão musical.

Neste ponto, torna-se importante destacar também os aspectos midiáticos da música como formas de expressão sonora. Segundo Heloísa Valente, o som "(...) controlável por parâmetros estéticos, pode ser delimitado pelo índice de reverberação, controle de canais, fazendo-se sobressair um ou outro, de acordo com a convenção estética de gênero ou do artista em particular" (2003, p.101). Isso sem falar nos aspectos ligados à circulação via cinema, rádio, TV, computador, etc; 
apoiando-se em modelos de divulgação que tornam os agentes produtores da música popular massiva em figuras proeminentes no chamado star system.

\section{3- Gêneros Musicais}

Não é incomum encontrarmos nos artigos e apresentações que envolvem a análise e compreensão da cultura midiática afirmações a respeito dos hibridismos, das interfaces e até da "imaterialidade" dos suportes comunicacionais na cultura contemporânea. Diante deste cenário, parece até "retrógrado" falar em gêneros musicais. No emtanto, uma rápida olhada sobre a circulação de produtos comunicacionais, seja na internet, nas lojas especializadas ou na crítica musical, permite ao observador atento perceber que o excesso informacional também pressupõe segmentação e que, muitas vezes, até para filtrar esse excesso, tanto os campos da produção, como da circulação e do consumo desses produtos, se valem de rótulos extremamente codificados. Não se deve confundir, então, formatos que continuam hegemônicos no campo musical com os artefatos tecnológicos responsáveis pela circulação dos produtos musicais.

Os gêneros seriam, então, gramáticas de produção do formato canção que envolvem estratégias produtivas e o sistema de recepção, os modelos e os usos que os receptores fazem desses modelos através das estratégias de leitura inscritas nos produtos midiáticos. Antes de ser um elemento imanente aos aspectos estritos da música, o gênero estaria presente no texto através de suas condições de produção e reconhecimento: "Momentos de uma negociação, os gêneros não são abordáveis em termos de semântica ou sintaxe: exigem a construção de uma pragmática, que pode dar conta de como opera seu reconhecimento numa comunidade cultural" (BARBERO, 1997, p. 302).

Assim, é preciso reconhecer que boa parte daquilo que é consumido como rock ou MPB, por exemplo, pressupõe valorações que nem sempre estão ligadas diretamente aos aspectos musicais de uma determinada canção. Intérpretes como Raul Seixas e Cássia Eller são rotulados como roqueiros, mesmo que, em determinadas canções, a sonoridade esteja plasticamente atrelada à MPB, mas como já foi dito anteriormente, a produção de sentido da música popular massiva envolve estratégias que ultrapassam os aspectos imanentes da canção popular massiva. 
Além de apontar para estratégias textuais ligadas ao campo da sonoridade, as noções de rock e MPB, por exemplo, apontam também para aspectos sociológicos e ideológicos do campo da produção e consumo da música popular massiva. Quando uma gravadora, um músico, um crítico ou um fã assumem ou negam determinado gênero, eles o fazem de acordo com referências que estão situadas à margem ou nos confins das estratégias textuais, que são interdependentes dos aspectos sociológicos e ideológicos da produção e do reconhecimento da música popular massiva, ou seja, a produção de sentido diante da música envolve modos de gostar/não gostar, modos de audição específicos ligados às apropriações da musicalidade e a interdependência entre as estratégias comunicacionais, tecnológicas e econômicas.

O gênero musical é definido então por elementos textuais, sociológicos e ideológicos, sendo uma espiral que vai dos aspectos ligados ao campo da produção às estratégias de leitura inscritas nos produtos midiáticos. Na rotulação, está presente um certo modo de partilhar a experiência e o conhecimento musical, ou seja, dependendo do gênero, elementos sonoros como distorção, altura e intensidade da voz, imagem, performance, papel das letras, autoria/interpretação, harmonia, modo, melodia e ritmo ganham contornos e importâncias diferenciadas.

Assim, pode-se notar que a rotulação é um importante modo de definir as estratégias de endereçamento de certas canções tanto em termos mercadológicos quanto textuais, incluindo aqui os aspectos plásticos e midiáticos da música popular massiva. Na verdade, as duas concepções, apesar de serem abordadas por diferentes estratos do pensamento comunicacional, só devem ser separadas para fins analíticos:

É comum alguém dizer que ouviu um samba de Tom Jobim, um rock dos Titãs ou mais uma canção romântica de Roberto Carlos. Todas essas designações de gênero denotam a compreensão global de uma gramática. Significa que o ouvinte conseguiu integrar inúmeras unidades sonoras numa seqüência com outras do mesmo paradigma. Sambas, boleros, rocks, marchas são ordenações rítmicas gerais que servem de ponto de partida para uma investigação mais detalhada da composição popular (TATIT, 1997:101).

O sentido e o valor da música popular massiva são configurados através do encontro entre a canção e o ouvinte, uma interação que está relacionada aos aspectos históricos e contextuais do processo de recepção, bem como aos seus elementos semióticos. É possível notar uma relação entre o rótulo musical e um suposto gosto 
do ouvinte, o que pressupõe uma certa afirmação sobre quem são os ouvintes para quem determinada música é dirigida. Em termos virtuais, os gêneros e suas configurações nas canções, descrevem não somente quem são os consumidores, mas também as possibilidades de significação de um determinado tipo de música para um determinado público. Na rotulação, está presente um certo modo de partilhar a experiência e o conhecimento musical.

De acordo com o gênero musical, elementos sonoros como distorção, altura e intensidade da voz, papel das letras, autoria e interpretação, harmonia, modo, melodia e ritmo ganham contornos e importâncias diferenciadas. Assim, se o solo de guitarra é fundamental em uma canção heavy metal, ele é completamente dispensável para uma banda de punk rock; se em uma canção denominada MPB, espera-se que o vocal esteja mais alto que os outros instrumentos para que se possa apreciar a melodia e as palavras cantadas, para o rock, em geral, é mais importante um bom refrão e a mesma altura para todos os instrumentos ou, dependendo do gênero, a guitarra pode estar mais alta que os vocais.

Os gêneros musicais envolvem regras econômicas (direcionamento e apropriações culturais), regras semióticas (estratégias de produção de sentido inscritas nos produtos musicais) e regras técnicas e formais (que envolvem a produção e a recepção musical em sentido estrito). Traçar a genealogia de uma canção popular massiva envolve localizar estratégias de convenções sonoras (o que se ouve), convenções de performance (regras formais e ritualizações partilhadas por músicos e audiência), convenções de mercado (como a música popular massiva é embalada) e convenções de sociabilidade (quais valores e gostos são "incorporados" e "excorporados" em determinadas expressões musicais). Assim, o crítico e/ou analista, pode partir das relações que vão do texto ao seu entorno midiático, dos músicos à audiência, do gênero aos relatos críticos, dos intérpretes ao mercado para dar conta das questões que envolvem a formação dos gêneros musicais.

\section{4- Performance}

Um dos campos privilegiados para se abordar a materialidade do sentido na música popular massiva é a observação das performances que envolvem não só a configuração dos gêneros musicais, bem como as características individuais dos 
diversos intérpretes em relação à música e à circulação de sua imagem nos dispositivos de divulgação dos produtos da Indústria Fonográfica. A performance musical é um ato de comunicação que pressupõe não só uma relação entre intérprete e ouvinte, bem como entre produto e consumidor. Nesse sentido, a performance aponta para uma espiral que vai das codificações de gênero às especificidades da canção. Mesmo que de maneira virtual, a performance está ligada a um processo comunicacional que pressupõe uma audiência e um determinado ambiente musical. Assim, podemos defini-la como um processo de produção de sentido e conseqüentemente, de comunicação, que pressupõe regras formais, ritualizações e comportamentos mercadológicos partilhados por produtores, músicos e audiência, direcionando certas experiências frente aos diversos gêneros musicais.

Os atos performáticos da música popular massiva estão diretamente conectados ao universo dos gêneros. Ser um astro do cenário heavy metal ou da música eletrônica exige relações com a audiência que seguem as características midiáticas dessas expressões musicais. Do mesmo modo que uma canção é, ao mesmo tempo, a música, sua respectiva performance e circulação, a audiência não consome somente as sonoridades, bem como as estratégias midiáticas e econômicas inscrita nos gêneros musicais. A relação entre ouvir música e responder corporalmente a determinada sonoridade é uma questão de convenção que, muitas vezes, parece "naturalizada" pelos consumidores de um gênero.

Além dos aspectos performáticos ligados ao ritmo e a execução musical, as configurações corporal e vocálica também estão ligadas às estratégias comunicacionais que envolvem a constituição da imagem dos intérpretes da música popular massiva, possibilitando o estabelecimento de vínculos entre músico e ouvinte, envolvendo a tênue relação entre intérprete, personagem e pessoa pública. As diferentes relações de intensidade sonora, reverberação, altura de voz em relação aos instrumentos musicais estão diretamente atrelados aos horizontes de expectativa dos diferentes gêneros musicais.

Esses aspectos da performance são fundamentais para a compreensão do que é considerado uma interpretação "autêntica", "cooptada", "impessoal" ou "verdadeira"; valorações decisivos para as estratégias de produtores, músicos e críticos no processo de endereçamento do produto musical ao seu público. Aqui, é 
possível notar de maneira clara como o entretenimento, a poética e a estética dos produtos da cultura popular massiva estão atrelados tanto às lógicas mercadológicas , bem como à estrutura musical das canções. A música popular massiva expressa emoções a partir do modo como as letras e sonoridades são interpretadas, embaladas e consumidas.

\section{5- Corpo, Voz, Cenário e Ritmo}

Toda expressão musical da cultura popular massiva indica modos de específicos de participação corporal diante da música. A maioria dos gêneros musicais pode ser associada a determinado modo de dança, que aqui não significa somente uma expressão pública de certos movimentos corporais diante da música e, sim, a corporificação indicada na própria expressão musical. Mesmo os gêneros que remetem a uma espécie de audiência passiva em termos de movimentos corporais, pressupõem alguma forma de relação rítmica e ritual com o corpo dos ouvintes. Quando dançamos (pelo menos em se tratando de danças codificadas socialmente), sujeitamos os movimentos de nossos corpos a regras musicais, o que revela um senso físico da produção de sentido diante da música. Dançar, como demonstram, por exemplo, o samba e o funk, é um modo codificado de processar a música. Isso sem falar nos aspectos gestuais que, muitas vezes, envolvem movimentos que funcionam como estímulos/repostas relacionados à própria estruturação de refrões e solos das canções.

Por outro lado, a "corporificação" da produção de sentido da música popular massiva está atrelada às dicções dos gêneros e canções, ou seja, toda execução musical implica determinadas questões: qual a voz que canta (ou fala)? Ou no caso de alguns subgêneros da música eletrônica: quais os corpos que tocam e dançam a música? Quem está tocando, falando e/ou cantando?A performatividade da voz ou do ato de "tocar" descrevem um senso de personalidade, um modo peculiar de interpretar não só uma música, como as próprias convenções de gênero, fator de importância para determinar os modos como canções e intérpretes serão embalados.

Diferentes canções e gêneros musicais apresentam timbragens, mixagens e dicções características; antes de se reconhecer quem ou o que se canta, a canção é endereçada ao ouvinte através de "modos de cantar e tocar". Assim, a vocalização e a 
interpretação de uma certa canção são "incorporações musicais” que, em geral, são atreladas a determinadas imagens associadas aos intérpretes ou aos gêneros musicais. Ouvir música é "incorpar” não só as vozes, instrumentos harmônicos e percussivos, bem como os corpos que tocam e executam essas canções. Só para citar um exemplo, vozes masculinas e femininas, mesmo quando interpretando a mesma canção, são definidas de maneira estrutural, como sons ouvidos de maneira interdefinida com outras sonoridades que, nesse caso, não estão, necessariamente restritas ao campo musical, mas também às vinculações econômicas e sociais desses corpos. Quando ouvimos a mesma canção, por exemplo, "Relicário", interpretada por Cássia Eller ou por Nando Reis, os aspectos semânticas da dicção ganham contornos diferenciados não só pelos diferentes modos de execução musical, bem como pelas possibilidades de produção de sentido corporificadas em um ou outro intérprete através das estratégias plásticas, midiáticas e econômicas associadas a estes intérpretes

A performance, ou seja, o ato de tocar, cantar e interpretar uma canção, está conectada aos diversos cenários presentes de forma virtual nos gêneros musicais e materializados nas canções. A produção de sentido da música popular massiva não deriva somente de uma configuração imperativa da canção, mas também de um posicionamento sócio-cultural de produtores, músicos e ouvintes. Vale lembrar que não se trata necessariamente de cenários presentes em mapas tradicionais. É possível falar dos cenários épicos do heavy metal, do sertão do baião, da Jamaica do reggae ou da metrópole do rap; na verdade esses exemplos não são referências a territórios em sentido tradicional, e sim, espaços associados a certas sonoridades, ou melhor dizendo, paisagens (com suas contradições, anseios e faltas) presentes na música popular massiva. Muitas vezes as próprias denominações, por exemplo, música caipira de raiz ou música sertaneja, carregam traços que envolvem imaginários espaciais presentes nas performances das canções. No caso da música caipira, há uma valorização de certa quietude, de um mundo desarticulado das novas tecnologias e das "modernidades", já a nomenclatura música sertaneja remete, hoje, ao agrobusiness, aos rodeios, ao "mundo pop" dos grandes produtores de grãos. Mas, do mesmo modo que a idéia dança pressupõe corpo e cenário, ela também está diretamente relacionada da noção de ritmo. 
A repetição, tão importante para análise da música, é fundamental para a produção de sentido e para a configuração das canções populares massivas. Essa demarcação envolve o encontro entre a métrica musical e a experiência de audição que abrange músicos e ouvintes, além do caráter circular de formatos e suportes midiáticos. Não por acaso, o ritmo e ou andamento são essenciais quando se fala de execução musical, ou seja, o ritmo é “(...) organização musical do tempo” (FRITH, 1996, p. 153). Tal como na configuração métrica, a dimensão temporal é espacializada na apreciação musical.

O ritmo está intimamente ligado à conformação temporal dos sons. Ouvir uma canção popular massiva é participar de seu desdobramento e, ao mesmo tempo, acreditar que esse desdobramento tem sido, ou será, definido, que nos levará a algum lugar. Tal como na configuração métrica, a dimensão temporal é especializada na apreciação musical e nos processos de circulação dos produtos culturais, e está diretamente ligada a boa parte do apelo sensorial exercido pela música popular massiva. Pode-se afirmar, então, que a dança (virtual ou atualizada) de uma canção, ou pressuposta em um gênero musical, é uma interpretação rítmica dos sons:

Meu ponto principal é que para a maioria da audiência de música popular massiva o modo mais fácil de entrar na música é quase sempre através do ritmo, através de movimentos regulares do corpo (nós todos podemos participar da ação percussiva da música, mesmo se nós não tivermos quaisquer habilidades musicais)." (FRITH, 1996, p.142)

Assim, voz, corpo, cenário e expressão rítmica são "incorporações musicais". Desse modo, a metodologia aqui pressuposta parte do princípio de que música popular massiva não está relacionada somente às esferas do campo da produção ou dos aspectos exclusivos da linguagem musical. Antes de mais nada, deve-se localizar a interdependência entre as estratégias plásticas, econômicas e midiáticas que envolvem o ambiente chamado música popular massiva. A produção de sentido da canção popular massiva está atrelada a uma história social dos usos e interpretações que podem ser relacionadas às performances em suas manifestações corporais, de suas características técnicas e econômicas, bem como à especificidade das vozes, dos timbres, dos ritmos e dos cenários musicais presentes na música contemporânea. Para finalizar, vale lembrar que essa separação entre os aspectos plásticos, midiáticos e econômicos da música popular massiva só é possível para fins analíticos, uma vez, 
que as estratégias de comunicação presentes nas expressões musicais são também expressões configuradas no entorno da Indústria Fonográfica.

\section{Referências:}

BARBERO, Jesus M. Dos Meios às Mediações : comunicação, cultura e hegemonia. Rio de Janeiro : Ed. UFRJ, 1997.

DIAS, Márcia Tosta. Os Donos da Voz: indústria fonográfica braileira e mundialização da cultura. São Paulo, Boitempo Editorial, 2000.

FABBRI, Paolo. El Giro Semiótico. Barcelona: Editorial Gedisa, 2000.

FRITH, Simon. Performing Rites: on the value of popular music.Cambridge/Massachusett: Havard University Press, 1996.

HEBDIGE, Dick. Subculture: the meaning of style. New York: Routledge, 1979

HERSCHMANN, Micael. O Funk e o Hip Hop invadem a cena. Rio de Janeiro: UFRJ, 2000.

JANOTTI JR, Jeder. Aumenta que isso aí é rock and roll: mídia, gênero musical e identidade. Rio de Janeiro:E-papers, 2003a.

À Procura da Batida Perfeita: a importância do gêenero musical para a análise da música popular massiva. Revista Eco-Pós. Rio de Janeiro: PósGraduação em Comunicação e Cultura da Esola de Comunicação/ UFRJ, vol.6, n.2, 2003b, p. 31-46.

Heavy Metal com Dendê: música e mídia em tempos de globalização. Rio de Janeiro, E-papers, 2004.

MARCHI, Leonardo di. A Angústia do Formato: uma história dos formatos fonográficos. E-Compós, número2, julho/2004. Disponível em: Acesso em 01/04/2005.

MIDDLETON, Richard. Studying Popular Music. Philadelphia: Open University Press, 1990. 
NAPOLITANO, Marcos. História \& Música. Belo Horizonte: Autêntica, 2002.

SHUKER, Roy. Understanding Popular Music. London/New York: Routledge,1994. .Vocabulário de Música Pop. São Paulo: Hedra, 1999.

STRAW, Will. Systems of Articulation, Logics of Change: communities and scenes in popular music. Cultural Studies. London: Routledge, v. 5, n. 3, p. 361-375, oct. 1991.

TATIT, luiz. Musicando a Semiótica. São Paulo: Annablume, 1997. . Semiótica da Canção: melodia e letra. São Paulo: Escuta, 1999. 2002. . O Cancionista: composição de canções no Brasil. São Paulo: Edusp,

.O Século da Canção. São Paulo: Ateliê Editorial, 2004.

VALENTE, Heloísa. As Vozes da Canção na Mídia. São Paulo: Via Lettera, 2003.

VERÓN, Eliseo. La Semiosis Social: fragmentos de una teoría de la discursividade. Barcelona: Gedisa Editorial, 1996.

ZUMTHOR, Paul. Performance, Recepção e Leitura. São Paulo: Educ, 2000. . A Letra e a Voz. São Paulo: Companhia das Letras, 1993. 